\title{
Mantra Dalam Teks Dharma Pewayangan
}

Oleh

I Made Dwitayasa

\begin{abstract}
Abstrack
The Wayang Kulit show in Java and Bali or in other regions in Indonesia besides functioning to complement the religious ceremony, as ruwatan, also give the noble values of pertinent relating to human life and spectacle with a very high aesthetic. Dharma Pewayangan is a guide (law, reference, ordinance, obligation, guidance) for puppeteer or dalang in carrying out his duties while performing Wayang Kulit. The understanding and implementation of dharma pewayangan teachings by dalang is a must and obligation because if deviate from the teachings will get the curse of Sang Hyang Catur Lokapala. Dalang uses a spell before the show begins until the end of the show. The spell function in the Wayang Kulit show is as a plea to God, self-guard, awakening the taksu, neutralizing bhuta-kala, and making tirta.
\end{abstract}

Keywords: mantra, dharma pewayangan,

\section{Pendahuluan}

Kesenian wayang hampir tidak dapat dipisahkan dari kehidupan masyarakat, khususnya di bidang keagamaan. Kitab-kitab itihasa dan purana adalah ensiklopedi dan sekaligus glossari kitab suci Veda. Namun perlu diketahui kehebatan seni pertunjukan wayang kulit tidak terlepas dari campur tangan seorang dalang. Kepiawaian seorang dalang membuat pertunjukan wayang kulit menjadi sangat digemari bukan saja oleh masyarakat lokal tetapi juga masyarakat internasional. Puncaknya pada tanggal 7 November 2003 di Paris Prancis, Unisco memproklamirkan pertunjukan wayang sebagai sebuah masterpiece of the oral intangible heritage of Humanity (Sedana, dalam Widnyana, 2005: 55). Pertunjukan wayang kulit diakui sebagai budaya warisan dunia, hal ini dikarenakan pertunjukan wayang kulit memiliki fungsi ganda yaitu sebagai media hiburan (tontonan) dan sebagai media tuntunan (pendidikan budi pekerti).

Pementasan Wayang Kulit di wilayah Jawa dan Bali maupun di beberapa daerah di Indonesia selain berfungsi pelengkap upacara keagamaan, sebagai ruwatan, juga memberikan nilai-nilai luhur adiluhung yang berkaitan dengan kehidupan manusia serta tontonan dengan estetika yang sangat tinggi. Pertunjukan wayang kulit dalam kegiatan ruwatan, sudah barang tentu mantra merupakan bagian terpenting yang harus dikuasai dalang. Oleh karena itulah menurut Sri Mulyono (1978: 2), Menjelaskan: di dalam pertumbuhannya, fungsi wayang juga telah mengalami beberapa perubahan, yaitu sejak dari fungsi sebagai alat suatu upacara yang ada hubungannya dengan kepercayaan (magis religius) hingga menjadi alat yang bersifat pendidikan dan sebagai alat penerangan, lalu menjadi bentuk kesenian daerah dan kemudian menjadi objek ilmiah. Sekarang banyak orang mengatakan bahwa wayang kulit adalah kesenian yang tinggi martabatnya, bahkan memberi predikat bahwa wayang kulit adalah kesenian klasik tradisonal adi luhung.

Bandem(1994) menjelaskan fungsi kesenian khususnya wayang kulit yang diyakini oleh orang Balimemiliki arti dan makna sebagai:(1) pengugah 
rasa indah dan kesenangan; (2) pemberi hiburan sehat; (3) media komunikasi; (4) persembahan simbolis; (5) penyelenggaraan kesenian normanorma masyarakat; (6) pengukuhan institusi sosial dan upacara keagamaan; (7) kontribusi terhadap kelangsungan dan stabilitas kebudayaan; (8) pencipta integritas masyarakat. Berkaitan dengan fungsi pertunjukan wayang kulit seperti yang diuraikan di atas maka pertunjukan untuk kepentingan upacara agama masih sangat mendominasi, khususnya yang berkaitan dengan panca yadnya. Berkaitan dengan upacara Panca Yadnya yang dilakukan oleh umat Hindu di Bali tidak lepas dari kesenian sebagai pelengkap maupun sebagai bagian dari upacara tersebut. Salah satunya adalah Pertunjukan wayang kulit. Pertunjukan Wayang kulit, yang terkait dengan sistem upacara merupakan suatu perwujudan dari religi disamping sistem keyakinan.

Fungsi kesenian bagi kehidupan masyarakat Bali, salah satunya sebagai alat komunikasi untuk memperkuat keyakinan, nilai-nilai, normanorma yang hidup dalam masyarakat. Selanjutnya kesenian itu secara universal dikaitkan dengan religi, karena dalam religi tertanam berbagai nilai dan norma yang membawa masyarakat kesuatu kemungkinan untuk berkomunikasi dengan hakekat tertinggi secara lebih tenang dan tepat. Komunikasi religi yang ditujukan kepada Tuhan atau para Dewa, biasanya dipergunakan mantramantra sebagai sarananya. Hal ini diyakini karena mantra merupakan bahasa pertama yang diterima oleh manusia sebagai wahyu Tuhan (sruti). Maharsi Manu yang disebut sebagai peletak dasar hukum digambarkan sebagai orang yang pertama memperoleh mantra dan mengajarkan mantra itu kepada umat manusia dan menjelaskan hubungan antara mantra dengan objeknya, demikianlah mantra merupakan bahasa ciptaan yang pertama (Titib, 2001: 437). Selain mantra-mantra yang harus dikuasai oleh seorang dalang, masih banyak lagi dharma atau kewajiban yang harus dilakukan oleh seorang dalang seperti arah adap saat makan, pantangan tidak makan surudan, makanan yang tidak boleh di makan, melakukan pewintenan dan lain sebagainya. Begitu ketat dan kompleksnya aturan-aturan yang menjadi warisan para leluhur, tidak aneh kalau tidak semua dalang yang dapat dan mampu melaksanakan aturan-aturan itu dengan sempurna, karena sebagai akibat dari kemajuan teknologi yang hampir menyentuh semua sisi kehidupan budaya manusia termasuk cara manusia berkesenian. Untuk menyikapi adanya ketegangan dan tarik menarik antara tradisi dan inovasi maka dibutuhkan keluwesan dalam menyikapi semua ini. Adanya hal-hal yang sifatnya tidak esensial dan substansial yang termuat dalam Dharma pewayangan yang dapat dimodifikasi sesuai dengan perkembangan zaman merupakan hal-hal yang tidak bisa dipungkiri (Purnamawati, 2005: 64). Oleh karena itu, banyak dalang yang tidak menggunakan mantra-mantra yang telah digariskan dalam Dharma pewayangan, hal itu bisa dikarenakan belum hafal, tidak punya referensi, dan sebagainya. Dalam fleksibelitas pelaksanaan ritual dalam agama Hindu sehingga mantra-mantra bisa diungkapkan dengan bahasa daerah (Bali). Namun demikian akan sangat lebih bagus lagi bila dilakukan dengan mantra. Di dalam agama Hindu memang bila mampu, bagus mengucapkan mantra bahasa Sanskerta karena mantra itu telah diturunkan melalui wahyu, lewat kesucian para rsi.

Dharma pewayangan adalah sebuah panduan (hukum, acuan, tata cara, kewajiban, tuntunan) bagi seorang dalang dalam melaksanakan kewajibannya disaat melakukan pertunjukan wayang kulit. Pemahaman dan pelaksanaan dharma pewayangan oleh para dalang adalah sebuah keharusan dan kewajiban karena jika menyimpang dari ajaran tersebut akan mendapat kutukan dari Sang Hyang Catur Lokapala. Dalam dharma pewayangan dijelaskan sebagai berikut:

yan sira mayun sudi ri putusan ing wayang palanya tan langgana ri jeng Sang Hyang Catur Lokapala apan sira umindahaken suci nirmala tatwa weruh ring adoh aprek ring tattwa- jnana terus malunga ring Tri Bhuana sangkanya ana sor-luhur, madyautama, pati-brata, sabda-bayu-idep ingala. Wenang pwa sira S.H. Catur-Loka-Pala umideraken satatanira S.H. Kawi-Carita, 
sira tangaran dadi dalang (Hooykass, 1973: 16).

Terjemahan Bebas:

Kalau siapa saja yang mau belajar Pewayangan/ Pedalangan, supaya tidak disalahkan oleh Sang Hyang Catur Lokapala. Karena akan memindahkan atau membicarakan kesucian filsafat, tahu dengan yang jauh dan yang dekat, tahu dengan bilangan yang ada dalam badan, dan yang ada di tiga dunia, sebabnya ada bawah dan atas, menengah dan utama, taat dan patuh, suara dan tenaga, pikiran jelek. Patutlah Sang Hyang Catur Lokapala mengelilingi, menempatkan Sang Hyang Kawi Carita, dialah namanya menjadi dalang. (Hooykass, 1973: 16).

Jadi, untuk dapat melaksanakan tugasnya, seorang dalang harus mengikuti aturan-aturan atau pedoman yang telah ditentukan dalam sastra. Adapun pedoman tersebut tersurat dalam lontar dharma pewayangan. Dalam dharma pewayangan tersebut seorang dalang dituntut untuk melaksanakan semua ajaran yang ada di dalamnya. Salah satu pedoman yang penulis bahas adalah tentang mantra-mantra yang digunakan oleh seorang dalang dalam pementasan Wayang Sapuh Leger. $\mid$

Hooykaas (1973) dengan judul buku Kama End Kala. Buku ini berisikan enam belas Dharma pewayangan dari berbagai wilayah di Bali. Secara umum semua Dharma pewayangan berisikan aturan atau pedoman seorang dalang dalam melaksanakan tugas dan kewajibannya sebagai pelaksanaan ajaran veda. Salah satu aturan yang diharuskan oleh buku ini adalah bahwa seorang dalang harus menguasai mantra-mantra yang tersurat di dalam ajaran tersebut sebagai persyaratan seorang dalang, khususnya untuk tugas ritualnya. Mantra-mantra yang diunggah dalam litratur ini tempatnya tidak terstruktur, sehingga dapat membingungkan dalam proses pembelajarannya.

Jika di lihat dari strukturnya, kelemahan mantra-mantra tersebut tidak tersususn dengan rapi, atau dengan kata lain bahwa mantra-mantra yang ada dalam dharma pewayangan itu tidak terurai sesuai dengan kebutuhan pada dalang saat melakukan pertunjukan. Oleh sebab itu perlu ada penelitian yang jelas mengenai srtuktur mantramantra yang digunakan oleh dalang.

Kelebihan pada buku tersebut bahwa terdapat berbagai jenis dharma pewayangan yang mengandung berbagai macam mantra yang digunakan oleh dalang dalam melaksanakan tugas dan kewajibannya. Jadi buku di atas merupakan ensiklopedia dharma pewayangan yang lengkap

\section{Pembahasan}

Kata Mantra berasal dari bahasa Sansekerta yang terdiri dari dua kata, yaitu man dan tra. Man ini mengandung pengertian manah (hati nurani) dan tra, yaitu trayati yang berarti menyampaikan. Sehingga mantra adalah suara yang disampaikan dari hati nurani kehadapan Hyang Widhi atau dewa-dewi atau bhatara-bhatari, agar beliau tersentuh dan tertarik oleh suara hati nurani.

Mantra disusun dengan menggunakan aksara-aksara tertentu, diatur sedemikian rupa sehingga menghasilkan suatu bentuk bunyi, sedang huruf - huruf itu sebagai perlambangperlambang dari bunyi tersebut. Untuk menghasilkan pengaruh yang dikehendaki, mantra harus disuarakan dengan cara yang tepat, sesuai dengan svara atau ritme dan warna atau bunyi. Mantra mempunyai getaran atau suara tersendiri, karena itu apabila diterjemahkan ke dalam bahasa lain, mantra itu tidak memiliki warna yang sama, sehingga terjemahanya itu hanya sekedar kalimat (Titib, 2003:439). Kaitanya dalam penelitian ini maka implementasi mantra yang dimaksud adalah penerapan mantra dalam dharma pewayangan yang di gunakan terhadap jro mangku dalang.

\section{Proses penggunaan Mantra dalam Teks Dharma Pewayangan}

Pada dasarnya mantra-mantra dharma pewayangan yang dipakai sumber acuan oleh para dalang merupakan hasil perasan dari beberapa Dharma pewayangan. Adapun struktur mantra yang dipakai dalam pertunjukan dapat dibagi menjadi 3 yaitu;

\section{Mantra sebelum pertunjukan}

Mantra-mantra sebelum pertunjukan 
adalah mantra yang digunakan oleh dalang mulai berangkat dari rumah sampai tiba ditempat pertunjukan yaitu terdiri dari:

1. Om.Ang Lingga Boktra Prayojana Suda Ya Namah Swaha (nafas deras hidung kanan = Brahma mangwayang).

Mantra ini digunakan saat dalang tiba di pintu masuk tempat "ngewayang" sang dalang berdiri sejenak dan mengheningkan cipta, merasakan nafasnya lebih deras pada hidung kanan, hal ini diyakini oleh para dalang bahwa Hyang Brahma memberikan restu. Secara Teologi mantra ini diperuntukan untuk memuja Dewa Brahma "ANG"=Bhrahma.

2. Om..Ung Lingga Boktra Prayojana Suda ya Namah Swaha (nafas deras hidung kiri = Wisnu mangwayang).

Jika setelah mengheningkan cipta di depan pintu gerbang dan merasakan nafas lebih deras padahidung kiri secara Teologi diyakini Dewa Wisnu telah memberikan restu pada jro mangku dalang "UNG=Wisnu.

3. Om..Mang Lingga Boktra Prayojana Suda Ya Namah Swaha (nafas kedua lobang hidung sama derasnya = Iswara mangwayang).

Hal yang sama dilakukan jro mangku dalang seperti tersebut diatas, dan dirasakan kedua hidung sama deras nafasnya berarti secara Teologi Dewa Siwa telah merestui pertunjukannya $\mathrm{MANG}=$ Siwa.

4. Dalamperjalanan: "Om Kamajaya tatkalaning lumaku jaya sidi ya namah swaha”.

Mantra ini ditujukan untuk memuja Sang Hyang Kamajaya agar dalam perjalan menuju tempat pertunjukan mendapatkan keselamatan dan kejayaan.

5. Setelah sampai di tempat pertunjukan: "Om Kamajaya wus prapta ngeka kesaktian ya namah swaha".

Secara teologi mantra ini ditujukan untuk memuja Sang Hyang Kamajaya untuk mendapatkan kekuatan atau kesaktian lahir dan batin pada saat mendalang.
6. Duduk: "Om ang, ung, mang, ang ah, ang ah, ang ah".

Mantra tersebut untuk memuja Sang Hyang Tri Murti yaitu Brahma,Wisnu dan Siwa.

7. Makan: "Om mahamerta ingsun amukti sarining suci nirmala, urip langgeng wisya punah wisya punah wisya punah".

Jadi mantra ini memuja Sang Hyang Amerta. Pada saat jro mangku dalang makan agar terhindar dari segala bahaya dan menghilangkan segala racun, dan menjadikan semua makanan menjadi amerta.

\section{Mantra saat Pertunjukan}

Setelah selesai mendapat boga atau prasmanan, dalang mulai bersiap menuju tempat nya "ngewayang". Duduk di blakang kelir tepat di bawah lampu blencong. Mantra-mantra di bawah ini adalah mantra-mantra yang biasa dipakai secara umum, kendatipun ada pula beberapa dalang yang tidak menggunakannya. Adapaun susunan mantra-mantra yang telah dirangkum dan di struktur sebagai berikut:

1. Duduk di bawah lampu blencong/di blakang kelir: "utpti (lahir): "Sa, Ba, Ta A, I, Na, Ma, Si, Wa, ya, Am Um Mam. "Stiti (hidup); I, A, Ta, Ba, Si, Ya, Wa, Si Ma, Na, Um Am Mam. Pralina (mati): A, Ta, Sa, Ba, I, Si, Wa, Ma, Na, Ya, Mam Um Am.

Mantra ini di ucapkan agar dalang mendapatkan kekuatan dari para Dewa dalam wujud Sang Hyang Dasaksara sebagai kekuatan Utpti, stiti, prelina (lahir, hidup dan mati).

2. Mantra lampu blencong: “Ang,Ang,Ang Bang Agni astra murub kadi kala mertyu anyapuh awu, durga lidek teka geseng, aku sang hyang Cintya gni, amlabar gni sejagat, buta, leak desti satrunku teka geseng”.

Mantra ini untuk memuja Sang Hyang Agni agar memberikan kekuatan kepada nyala api Blencong, serta memusnahkan segala ancaman yang ingin mencelakakan sang dalang. Selain itu dilihat dari kaca mata batin, mantra ini adalah mencerminkan kekuatan 
dalam sang dalang sebagai api batin. Lebih jauh lagi, agar dalang selalu mempunyai semangat yang berkobar-kobar dalam menjalankan tanggung jawabnya sebagai seorang dalang.

3. Ngundang taksu. "Ih..taksu ngidep buwana kena, sang hyang manik terus manik astagina, sang taksu dibya, atinku Surya Candra anyunari sebuana, ala ayu katon ring idep, teka jati ening, teka dudupan, teka dudupan, teka dudupan".

Mantra ini diucapkan untuk mengundang Sang Hyang Taksu, agar pertunjukan dapat memukau penonton lewat tuntunan dan tontonannya. Lebih spesifik lagi, agar segala yang akan diucapkan atau dilakukan dalang, semuanya terang bendrang, jelas seperti siang disinari matahari, dan gelap seperti disinari bulan. Dengan demikian segala yang disampaikan menjadi terang bendrang tanpa halangan yang berarti.

4. Pengraksa Jiwa: "pakulun sanghyang panca pandawa umor ring akasa, Nakula Sahadewa ring cakepan kalih, Arjuna ring lontar, Darmawangsa ring sastra, Bima ring kelatning lontar, urip apageh lila ning wigna paramasakti ya namah swaha, Om Am Mam Um Om". Mantra ini diucapkan untuk memuja Sang Hyang Trimurti, Sang Hyang Sastra dan memuja kekuatan Panca Pandawa agar memberikan perlindungan kepada jiwa sang dalang.

5. Pengasih. Sarana 'base' "pakulun sanghyang tunggal amasang guna kasmaran, bhuta leak sih, jatma manusa sih, dewa betara sih, Ong Ang antara pantara sarwa sih manembaha lila suksma ya namah swaha".

Mantra ini untuk memuja Sang Hyang Tunggal dalam sifatnya memberikan cinta kasih, agar semua mahluk baik yang nyata maupun astral, bisa kasih kepada dalang. Dengan demikian dalang merasakan mendapat dukungan batin dan ketenangan dalam memunaikan kewajibannya.

6. Pengeger; "pakulun sanghyang tiga Wisesa amasang guna pengeger, wong lanang, wadon geger, kedi geger, apupul ring arepku awijah lulut angrungu ingsun, pawak ingsun sanghyang Semara, waneh sira andulu sanghyang samara waneh sira andulu ingsun, teka olas den pada asih, isep, isep, isep,an gung mang raja karya murti saktyem patastra ya namah swaha".

Mantra ini untuk memuja Sang Hyang Tiga Wisesa untuk memohon kekuatan taksu untuk menarik penonton sebanyak-banyaknya berkumpul menyaksikan pertunjukannya. Keinginan penonton seperti kena panah asmara, sehingga tidak merasa bosan menikmati sajian sang dalang.

7. Pengalup: "ingsun angidep aken sanghyang guru rekan kama tantra, swaranku manik astagina andawut atma juwitane wong kabeh, asih welas mulih ring ati, edan ulangun mulih ring nyali, oneng lulut mulih ring papusuh, sing teka pada rna, sing tka pada rna, sing tka pada rna".

Mantra ini hampir sama fungsinya dengan "pengeger", namun pada mantra ini lebih dikususkan untuk memohon kekuatan retorika (dialog, monolog) dan vokal atau tembang atau "tandak" agar mampu menarik hati nurani serta menyenangkan pendengarnya. Hal ini dilakukan karena dalang sering melakukan monolog dan dialog secara spontan sesuai dengan kemampuan kreativitasnya. Oleh sebab itu yang dipuja pada mantra ini adalah Sang Hyang Guru Reka, yaitu Tuhan dalam kekuatannya menciptakan sesuatu yang baru dan brmanfaat.

8. Nebah gedog (membuka tutup kotak/kropak wayang dengan memukul tutup gedo $3 \mathrm{x}$ ): "atangi sanghyang Samerana angringgit amolah cara". Catatan: tutup gedog diletakkan di sebelah kanan dalang, dengan posisi tutup gedog yang lebar mengarah ke depan.

Mantra ini diucapkan untuk memohon restu kepada "Sang Hyang Catur Dalang (dalang Samerana, dalang Anteban, dalang Jaruman, dalang Sampurna". Namun dalam mantra ini hanya diwakili oleh dalang "samerana" 
sebagai dalang yang tertua.

9. Nebah kain kasa penutup Wayang. "Om Brahma munggah dewa urip jeng".

Mantra ini diucapkan untuk memuja dewa Bhrahma agar memberikan kekuatan hidup kepada semua wayang sehingga lakon yang disajikan dapat memberikan tuntunan dan tontonan hidup dan kehidupan nyata. Catatan: wayang yang diambil pertama kali setelah membuka kain kasa oleh dalang adalah wayang pemurtian dan ditancapkan di sisi kanan dan kiri kelir.

10. Nyolahang Kayonan: "Ong Sambu mulih ring Wisnu, Sangkara mulih ring Mahadewa, Ludra mulih ring Brahma, Maheswara mulih ring Iswara, Iswara mulih ring Kayonan, Kayonan mulih ring Ati”.

Mantra ini untuk memuja Dewata Nawa Sanga, dimana pengucapannya melingkar ke arah kiri "utara yana" mulai dari ersanya/ dewa Sambu. Mantra ini diucapkan sebelum dalang menarikan wayang kayonan. Setelah selesai mengucapkan mantra ini, barulah dalang menarikan kayonannya (Hooykaas, 1973: 22).

\section{Mantra Sesudah Pertunjukan}

Setelah Pertunjukan selesai biasanya dalang menghaturkan beberapa sesaji sesuai dengan desa kala patra desa setempat, atau melakukan ritual sesaji khusus jikalau berkaitan dengan wayang sapuleger dengan sesaji tadah Kalanya. Namun yang paling utama adalah saat dalang membuat tirta sudamala dan atau sapuleger yang sering disebut dengan "tirtan wayang". Dalam penelitian ini, penulis akan mengambil salah satu model mantra yang digunakan oleh dalang saat membuat tirta dan mantra saat melakukan pengelukatan. Namun sebelum dalang membuat tirta dan menghaturkan sesaji, terlebih dahulu dalang melakukan ritual kecil dengan beberapa mantra, sepeti halnya seorang pinandita dalam "muput" sebuah upacara. Adapun ritual tersebut adalah pranayama (mengatur pernafasan), penyucian angga sarira, penyucian sarira, pengening kayun, dilanjutkan dengan gayatri mantram. Setelah itu dalang melanjutkan menghaturkan sesaji yang telah disediakan yang didahului dengan ngelukat semua banten seperti; pejati, peras, penyeneng, daksina alit/agung, suci, pengambean, prayascita, segehan dan sebagainya. kemudian dilanjutkan dengan membuat tirta, dan ngelukat orang yang diupacarai jika diperlukan, seperti dalam sapuleger.

\section{Mantra Membuat Tirta}

Tirta Pengelukatan Panca Dewa:

Om, gangga muncar saking purwa, tininggalana telaga noja, jambangania selaka, tinanceban tunjung petak, padyusanira betara Iswara, matemahan tirta sanjiwani, pangilanganing papa petaka, moksah ilang Sang namah.

Om, gangga muncar saking daksina, tininggalana telaga noja, jambangania tembaga, tinanceban tunjung bang, padyusanira betara Bhrahma, matemahan tirta kamandalu, pangilanganing sarwa wigena, moksah ilang Bang namah.

Om, gangga muncar saking pascima, tininggalana telaga noja, jambangania emas, tinanceban tunjung jenar, padyusanira betara Mahadew, matemahan tirta Kundalini, pangilanganing lara roga, moksah ilang Tang namah.

Om, gangga muncar saking utara, tininggalana telaga noja, jambangania wesi, tinanceban tunjung ireng, padyusanira betara Wisnu, matemahan tirta mahamerta, pangilanganing sarwa satru, moksah ilang Ang namah.

Om, gangga muncar saking madya, tininggalana telaga noja, jambangania amancawarnal kawah, tinanceban tunjung manca warna, padyusanira betara Siwa, matemahan tirta pawitra, pangilanganing tri mala, panca mala, dasa mala, moksah ilang ing namah.

\section{Mantra Ngelukat}

Dalam Dharma pewayangan Hooykaas 1973, chapter 21, menjelaskan proses dalang saat ngelukat di hari tumpek wayang atau dalam upacara anyapuh leger sebagai berikut:

"sang amangku dalang tedun saking genahe ngewayang, nuju natah paumahan 
yadin sangah sang inupakara, nglukat sang inupakara wetu ring wuku wayang”.

Terjemahan:

Dalang turun dari tempatnya mendalang, menuju ke halaman atau ke tempat suci dari rumah yang diupacarai yang lahir pada wuku wayang (sukerta).

\section{Mantra:}

Ong Yang Sarwagni mahojwala, wisaya, papa-klesa, utpatadityam, supranaya namah (Hooykaas, 1973: 280).

Arti: Ya Tuhan dalam wujud api yang maha dahsyat melebur segala kesalahan, noda maupun dosa.

Ong serdah paduka betara Siwa Murti sakti, anibakaken tirta kamandalu, winadahan kundi manik, maka suklaning bhuana agung bhuana alit maka uriping bhuana kabeh, amuburana ujar ala, tuju, teluh, desti trangjana, kalukat denira tirtan betara Siwa Murti Sakti, siniratan muncrat mancur, angilangaken papa klesa, dasa mala manusa kabeh, Ong sidi rastu tatastu astu swaha.

Terjemahan:

Tuhan dalm wujud Siwa maha sakti, memercikkan air suci yang ada di dalam kendi mas manikam, sebagai penyucian makrokosmos dan mikrokosmos, yang menghidupkan dunia tersebut, dan membakar serta melebur segala nista, teluh, penyakit, segala ilmu gaib, dilebur oleh percikan air suci dewa Siwa yang maha sakti, percikan maha suci ini menghilangkan segala segala kesengsaraan semua mahluk (manusia), Tuhan semua kehendakmu pasti terwujud (dokumen pribadi dalang Selisihan Klungkung).

Ong ayu werdhi yasa, wrdhi pradnyan suka sriya, dharma sentana wredinca, santute sapta wredayah, Ong yawat meru stuti dewah, yawat gangga mahitale, candrarka gangane yawat, tawat wijaya bhawet (Hooykaas, 1973; 276).

\section{Penyimpenan Wayang}

Setelah kegiatan ritual selesai, dalang memasukkan semua wayangnya ke dalam gedog/kropak. Sebelum menutupnya dalang mengucapkan sebuah mantra: Om tatwa carita merem ye namah swaha. Mantra ini dimaksudkan untuk mengembalikan wayang sebagai benda mati. Secara filosofis agar dewaning ringgit (yang menjiwai atau memberikan roh kepada semua wayang) kembali ke alam peristirahatannya "merem".

Fungsi Mantra dalam Teks Dharma Pewayangan Jro Mangku Dalang

Seperti telah diuraikan di atas pada Bab II, bagian Implementasi Mantra, bahwa mantra merupakan suara yang disampaikan dari hati nurani ke hadapan Sang Hyang Widhi atau dewa dewi, bhatara-bhatari agar beliau tersentuh dan tertarik oleh suara hati nurani itu. Oleh sebab itu semua mantra-mantra yang digunakan merupakan akses komonikasi teologis bagi seorang dalang.

\section{Fungsi Permohonan Kepada Tuhan.}

Secara kasat mata, pertunjukan wayang kulit hanya dinilai dari apa yang terlihat di depan mata dan didengar serta dirasakan saja. Namun secara umum, dalam strata komonitas masyarakat, banyak yang tidak memahami bahwa ada sesuatu kekuatan yang tidak kasat mata ikut memberikan jiwa dan roh sehingga pertunjukan menjadi lebih berbobot. Permohonan kepada Tuhan dilakukan sebelum berangkat "ngewayang". Di sanggah atau merajan, sang dalang menghaturkan sesaji seperti "daksina" (ngelinggihang daksina) agar Tuhan memberkatinya dalam melakukan pertunjukan.

Mantra:

Ong Sang Hyang Baruna, Malinggih ring sasari, ring sasantun, Sang Hyang wisnu Amarisuddha salwiring gaweningulun, siddha kaparisuddha, denira Battara Wisnu, Ong Suddha wari Wastu ya namah swaha.

Terjemahan:

Tuhan dalam wujud Sang hyang Baruna, yang berstana di sesaji "sesantun" Sang Hyang Wisnu mensucikan semua yang aku kerjakan, semua di sucikan oleh dewa Wisnu, semoga semua terlaksana atas berkahMu (Hooykaas, 1973: 278). 
Selain hal tersebut di atas, dalang juga menggunakan Kancana Ringgit sebagai upakaring dalang (sesaji dalang) yaitu:

Kropaknya mungguh ring Bayu; abang warna, AM swaranya. Dalangnya mungguh ring idep; putih warnanya, kaya selaka linebur, UM swaranya, rahina tan kadalwan ginamelnya, ring sunya-loka desa ya wenang, wayangya mungguh ring sabda kuranta warnaya mahening, MAM swaranya. Indik pawakanya, ring otot jajar kunang maka pasuk wetunya.

Terjemahan:

Kropak wayang di tempatkan sebagai tenaga, warnanya merah, swaranya AM (Brahma), Dalangnya di letakkan pada pikiran, warnanya putih seperti perak di lebur, swaranya Um (wisnu), wayangnya di letakkan di suara/mulut, oranye warnanya, swaranya MAM, otot jajar sebagai keluar masuknya (Hooykaas, 1973: 70).

Dilanjutkan dengan mohon Panugrahan.

Salwiring ngalekas denira wenang, sarana toya sugyang $3 x$. Arti: mantra mohon anugrah agar segala yang di kehendakil lakukan bisa terwujud dengan sarana air dipakai mencuci muka $3 x$.

\section{Mantra:}

Siwa ring bayu, Sada-Siwa ring idep, Parama-siwa ring sabda, sah-Siwa masarira kabeh, OM YAM Siwa-Lingga-Suddhaya namah, AM, AH, AH, AM, YA.

Terjemahan:

Dewa Siwa pada tenaga, Dewa Sada-Siwadi pikiran, dewa parama-siwa di swara, dengan berbagai macam wujud, Om Siwa sebagai Lingga memberkati.

Mesegeh (sesaji kepada Bhuta (Hooykaas, 1973:280).:

Ong Bhuta ring pakarangan, Bhuta ring pakubonan, iki tadahen sajinta, ri uwusta aneda aywa marangke mwah, ndan pada raksa-rumaksa mangda kayowanan.

Terjemahan:
Tuhan dalam wujud Bhuta di dalam rumah, di dalam pondok, ini silahkan nikmati makananmu, setelah selesai makan jangan kembali kesini lagi, harus saling pengertian agar selalu terlihat muda.

Sebagai sebuah catatan, bahwa mantramantra yang digunakan dalang sebelum berangkat "ngewayang tidak tercantum dalam Dharma pewayangan secara utuh, namun dipetik dari beberapa sumber Dharma pewayangan dan disesuaikan penggunaannya. Oleh sebab itu setiap dalang mempunyai cara masing-masing dalam memohon berkah kepada tuhan.

Di dalam pertunjukan wayang kulit, mantra merupakan salah satu item yang mampu memberikan dan mengangkat kualitas pertunjukan menjadi lebih maksimal. Selain dipakai sebagai permohonan sesuatu seperti permohonan maaf, mantra dapat digunakan secara langsung oleh Jro Mangku Dalang menjadi bagian "antawecana" pertunjukannya. Mantramantra tersebut disesuaikan dengan konteks serta tokoh yang menggunakannya. Tokoh-tokoh wayang yang sering menggunakan mantra sebagai "antewacana" adalah tokoh pendeta, begawan, rsi, dan juga para dewa. Selain itu, tokoh-tokoh lain seperti kesatria dan bahkan tokoh raja raksasa juga sering menggunakannya sesuai dengan kebutuhan cerita. Seperti misalnya pada adegan "newasraya"; yaitu adegan dimana salah satu tokoh memohon anugrah atau kesaktian kepada dewa tertentu, maka tokoh ini akan menggunakan mantra-mantra tertentu untuk menurunkan dewa yang dipujanya dari bentuk transendent ke dalam bentuk imanent.

Selain adegan "newasraya" mantra juga digunakan saat adegan perang, dimana saat seorang tokoh ingin memperlihatkan kesaktiannya, biasanya dilakukan dengan berbagai cara, seperti: memberi mantra kepada senjata sebelum senjata tersebut dilepaskan untuk membunuh musuhnya. Kemudian disaat tokoh merubah wujudnya menjadi mahluk tertentu "nyuti rupa", serta untuk mengeluarkan ajian tertentu. Mantra, pengeger, pengalup, ataupun agni anglayang sering digunakan di dalam cerita-cerita tertentu. Dengan demikian, mantra merupakan bagian sekaligus roh 
dari petunjukan tersebut.

\section{Sebagai Penjaga Diri}

Mantra-mantra yang digunakan seperti tersebut diatas merupakan bagian dari pertunjukan, dan salah satu diantaranya merupakan mantra untuk menjaga diri. Mantra tersebut adalah manta "pengraksa jiwa" seperti tersebut di atas. Selain itu mantra "pengeger" "pengalup", "pengasih" juga dapat dikatagorikan sebagai mantra penjaga diri. Mantra ini sangat penting digunakan karena diyakini selalu bisa melindungi keselamatan dalang beserta anggotanya. Mantra-mantra tersebut diucapkan dengan menggunakan saranasarana tertentu. Mantra di bawah ini menggunakan sarana makan sirih, "iduh"; ludah merah/ludah sehabis makan sirih. Nginang:

Pukulun Sang Hyang Tiga Wisesa, amasang guna pangeger, wong lanang geger wong wadon geger wong kedi geger apupul ring arepku awijah angrungu ingsun pawakan ingsun Sang Hyang Smara waneh sira andulu Bhata Smara waneh sira andulu ingsun teka welas den pada asih isep, 3 ANG UNG MANG raja karma murti saktiem patastra suddha ya namah"

Terjemahan:

Ya Tuhan dalam wujud tiga kekuatan memasang guna-guna menghebohkan, laki-kali heboh, wanita heboh, banci heboh, berkumpul di depanku bersimpuh mendengarkan aku, karena aku Sang Hyang Asmara, kecuali mereka bosan dengan asmara maka bosanlah denganku, datang dengan belas kasihnya, Bhrahma, Wisnu, Siwa, semua pekerjaanku terlaksana dengan bersih dan damai.

Pangeger dengan sarana tembakau.

"Ingsun angidep Sang Hyang Smara andarat, andahut atma-jiwane wong kabeh, sing angrungu, 'sing andulu, swara solahku angringgit, teka welas den pada asih, teka asih-asih tan apasah ket sumaket, teka asih, jeng”.

Terjemahan:

Aku merapalkan dewa pengikat asmara, menarik jiwa semua orang, yang mendengar, yang memperhatikan, suara dan tingkahku mendalang semua memelas kasih, datang kasih-kasih tidak bisa lepas, rekat melekat, kasih, kasih, kasih.

Mantra:

Pukulun Sang Hyang Panama Wisesa pangraksa jiwa, Sang Hyang Taya angraksa bayu, Sang Hyang Purusa Wisesa angraksa sabda, Sang Hyang Cintya angraksa idep, Sapa wani paksa alane, Bhuta leyak pada nembah, Sarwa-wisesa nembah, janma manusa nembah, Dewa Bhatara asih, apan aku Sang Hyang Tiga Wisesa, luhur ing Sang Hyang Om-Kara Mula, alungguh ring Nada Licin, 'sing ala paksane urung, leka wedi, teka asih, patuh, $3 X$.

Terjemahan:

Tuhan yang menguasai jiwa, Tuhan penguasa tenaga, Tuhan penguasa suara, Tuhan, penguasa pikiran, siapa brani pasti kena musibah, mahluk astral sujud, segala yang sakti sujud, manusia sujud, para dewa memberi kasih, karena aku Tuhan dalam wujud tiga kekuatan, di atas semua yang tunggal, terletak di titik yang suci bersih, semua bahaya menghindar, karena takut, dan menjadi memberi kasih, serta menjadi pengikutku.

Demikianlah beberapa mantra yang digunakan oleh dalang untuk melindungi dirinya dari segala ancaman baik yang datang dari manusia maupun yang datang dari mahluk-mahluk astral.

\section{Fungsi Membangkitkan Taksu}

Pertunjukan Wayang Kulit salah satu bentuk karya seni yang dapat dipakai sebagai pencarian nilai-nilai luhur dari sistem filsafat dan etika yang bersumber pada ajaran agama. Melalui pertunjukannya Jro Mangku Dalang berperan sebagai komunikator sosial, filsafat dan kerohanian yang dapat menawarkan pendidikan moral, dengan metode yang sangat menarik. Penyampaiannya tidak secara dogmatis sebagai suatu indoktrinasi, melainkandengan cara menawarkan kepada penonton. (Hasim Hamir, 1994:19). Untuk mendapatkan pertunjukan seperti keinginan Hasim Amir di atas tidaklah seperti membalikkan telapak tangan, harus melalui 
proses pembelajaran yang sangat panjang. Hal ini disebabkan karena pertunjukan wayang kulit adalah kesenian multi fungsi, dan multi telent, yang menjadikan kesenian ini sebagai seni yang total teather. Secara sederhana pertunjukan yang baik dan menarik dikatakan sebagai "balihbalihan metaksu", atau sebuah kesenian yang mampu memberikan santapan bathin. Widnyana dalam bukunya Pembelajaran Seni pedalangan bali menyebut "taksu" sebagai kekuatan dalam dalang atau inner power (2007: 191).

Widnyana juga menjelaskan bahwa Taksu bukan saja di gunakan untuk kesenian, tetapi bisa masuk ke ranah di luar kesenian seperti taksu pedagang, taksu pejabat dan sebagainya. Bobot taksu yang penting adalah jiwanya atau spiritnya. "Taksu itu seperti angin, kita hanya bisa merasakannya. Oleh sebab itu apapun profesinya perlu taksu, baik di dalam maupun diluar seni. Di dunia pedalangan, selain skill dan telent, taksu juga diyakini bisa datang secara spiritual melalui mantra-mantra yang telah digariskan dalam Dharma pewayangan. Istilah memanggil taksu dalam dunia pewayangan dikenal dengan istilah "ngundang taksu" atau "ngelinggihang taksu".

Ngundang taksu. "Ih.taksu ngidep buwana kena, sang hyang manik terus manik astagina, sang taksu dibya, atinku Surya Candra anyunari sebuana, ala ayu katon ring idep, teka jati ening, teka dudupan, teka dudupan, teka dudupan". (cacatan: Mantra ini di kutif dari Dharma pewayangan Hooykaas yang ada pada skripsi ini).

Mantra:

Taksu Dharma pewayangan (Hooykaas, 1973; 10, poin 52).

Pukulun Sang Hyang Panca Pandawa, umor ing akasa, Nakula Sadewa ring takepan kalih, Arjuna ring lontar, Dharma-tanaya ring lontar sastra, Bhima ring belat ning lontar, urip apageh, lila nirwighna parana sakti, Om Am Mam Um Om.

Terjemahan:

Ya Tuhan dalam wujud Panca Pendawa yang sudah menyatu di angkasa, Nakula Sahadewa menjadi kotaknya, Arjuna menjadi lembaran lontarnya, Dharmawangsa menjadi hurufnya, Bima sebagai pengikat lontar, hidup kekal, bahagia tiada halangan, Tuhan Bhrahma, Siwa dan Wisnu.

Taksu "ngisep Sastra": Sang Hyang Siwa angisep guna, Sang Hyang Saraswati angisep sastra, Sang Hyang Kawiswara angisep tatwa carita, isep, $3 x$, jeng.

Terjemahan:

Dewa Siwa menyerap segala guna, Hyang Saraswati menyerap segala sastra, Sang Hyang Kawiswara membuat segala cerita.

Mantra ini digunakan agar segala yang dipelajari bisa meresap ke dalam tubuh dalang. Sarana bebas.

Taksu Maha Sakti:

Om Maha-sakti, Dewa sakti, sidhi puja ni nghulun.

Terjemahan:

Tuhan maha sakti, dalam bentuk sinar suci maha sakti, terwujud segala puja dan keinginanku.

Mantra ini memuja kebesaran dan keagungan Tuhan beserta segala manifestasinya agar memberikan kekuatan kepada dalang.

Sebagai sebuah karya seni, pertunjukan wayang kulit seperti pula kesenian lainnya merupakan suatu kesenian yang menawarkan estetika. Dalam sebuah karya seni, unsur wujud, bobot merupakan hal yang sangat penting sehingga mampu memberikan estetika yang bagus dalam penampilannya. Wujud terdiri dari bentuk dan struktur, bobot terdiri dari ide, pesan dan suasana, sedangkan penampilan terefleksi lewat telent (bakat), skill (kemampuan) dan sarana (alat). Mantra-mantra yang digunakan oleh Jro Mangku dalang bisa masuk ke dalam tiga unsur seni tersebut. Hal ini dapat dijelaskan sebagai berikut; bahwa di dalam wujud; mantra telah memiliki bentuk dan struktur yang jelas. Kemudian dalam unsur bobot, mantra bisa masuk sebagai pesan di dalam suasana tertentu.

\section{Fungsi Menetralisir Bhutakala}


Sumber benda-benda di alam ini terdiri dari lima unsur, yaitu Prthiwi (tanah), Apah (air), Teja (api), Bayu (angin) dan Akasa (ether). Kelima unsur alam inilah yang membentuk realita dunia ini. Unsur-unsur matrial yang menjadikan realita dunia inilah yang disebut Bhuta (Wikarman, 2006: 6). Di dalam dunia pewayangan kelima unsur Panca Maha Bhuta ini juga ada dalam aparatus pertunjukan wayang. Tanah (pertiwi) disimbulkan batang pisang, air (apah) dan angin (bayu) disimbulkan wayang Kayonan, Api (teja) disimbulkan Blencong, akasa (ether) disimbulkan pada kelir.

Bhuta sesuai dengan sifatnya, ia pasif, tidak bergerak. Setelah mendapat sentuhan tenaga barulah ia bergerak. Tenaga atau energi dalam bahasa Yoga adalah "prana". Dalam Bahasa Agama disebut Kala. Bersatunya bhuta atau benda-benda matrial dengan kala atau tenaga, maka bendabenda matrial yang sangat besar dan banyak ini lalu bergerak dengan sangat hebatnya Demikian halnya pada saat dalang melakukan pertunjukan wayang, sebelum dan sesudah pertunjukan pasti ada sesaji untuk Bhutakala, dengan maksud mentralisir kekuatan tersebut menjadi kekuatan positif. Dalang sangat berhak melakukan ritual ini karena telah ditentukan dalam Dharma Pewayangan. Adapun kalimat tersebut adalah sebagai berikut:

Sang Amangku Dalang mawak gumi, mawak Bhuta, mawak Dewa, dalang ngaranya waneh. Karana dadi Siwa, karana dadi Parama-Siwa, karana dadi Sada-Siwa, karana dadi Hyang Acintya (Hooykaas, 1973: 18).

Terjemahan:

Dalang bisa sebagai bumi, sebagai Bhuta, sebagai dewa, tiada lain itulah dalang, sebabnya menjadi Siwa, Parama-Siwa, dan Sada-Siwa.

Salah satu bentuk persembahan kepada Bhutakala yang tercantum dalam Dharma pewayangan Hooykaas adalah dalam bentuk Caru Gelar Sanga, Pada halaman 272. Mantra atau sesapan yang digunakan adalah sebagai berikut:
"Ong Sang Praja, Sang Detya, Sang PusehPati, Sang Dengen, Sang Raksasa, Sang Wil, Sang Kala Karung, Sang Kala Agung, Sang Kala Sabhumi, sang Kala Pajagalan, Sang Kala Udug Basur, Sang Kala Ulu Singha, Si Dewi Yoni Sakti, mapupul lintang kabeh sun tingalin baktya, ulun iriki, ulun luputa ring lara-roga. ONG, SANG, BANG, TANG, ANG UNG, MANG, Siwaya; Ong Dewa Bicarya namah, Kala Bicarya namah, Bhuta bicarya namah, aku Kama bicarin ya namah, ONG Joko singa aku gurumu, sarin tahun”. TELAS (Hooykaas, 1973: 272).

Terjemahan:

Tuhan dalam wujud Sang Praja, Sang Detya, Sang Puseh-Pati, Sang Dengen, Sang Raksasa, Sang Wil, Sang Kala Karung, Sang Kala Agung, Sang Kala Sabhumi, sang Kala Pajagalan, Sang Kala Udug Basur, Sang Kala Ulu Singha, Si Dewi Yoni Sakti, berkumpul sangat banyak melihat baktiku disini, terhindar dari sengsara, Tuhan dalam aksara suci Sang, bang, Tang Ang, Ung, Mang, Siwa, Tuhan dalam wujud dewa bicarya, Kala Bicarya, Bhuta Bicarya, aku Kama Bicarya, Ong dalam Joko Singa aku Gurumu selamanya. Selesai.

"Ih Bhuta sama presama Kala Wigraha, iki sajyanira sowang-sowang Ong Ang Mrtaya namah (Hooykaas, 1973: 282).

Terjemahan:

Wahai para Bhuta dana para Kala perusak, ini santapanmu telah tersedia masing-masing, nikmatilah seperti Amerta.

"Ih Bhuta presama Kala Wigrha, iki tadahen sajianta sowang-sowang, yan kurang sajianku, enak amet marikanang pasar agung, wus anadah enak pamuliha pwa kita, aywa mewali muah, aywa mamigena ingsun, aywa mamigena sang aduwe karya, poma $3 x$ (dokumen pribadi Jro Dalang Widnyana).

Terjemahan:

Wahai para Bhuta dan juga para Kala, ini nikmati makananmu bwrsama-sama, kalau kurang pemberianku, silahkan ambil lagi di pasar yang 
menyediakan santapanmu, setelah itu silahkan pulang ketempatmu dan jangan kembali lagi, jangan mencelakai aku, jangan mencelakai orang yang sedang beryadnya ini. Silahkan 3x.

Pada dasarnya, semua mantra Bhutakala adalah bertujuan untuk menetralisir mahlukmahluk astral agar tidak mengganggu kehidupan seisi dunia ini. Bhutakala juga mahluk ciptaan Bhrahma seperti yang disebutkan dalam Dharma Sastra yang dikutif oleh Wikarma. Dalam bukunya yang berjudul Caru Palemahan dan Sasih menerangkan sebagai berikut: para golongan Bhutakala ini, yang termasuk golongan Sadya adalah diciptakan oleh Brahman. Golongan Sadya itu terdiri dari makhluk astral yang tingkatannya lebih rendah dari Dewa-dewa. Mereka mempunyai sifat bermacam-macam.

\section{Fungsi Membuat Tirta}

Seperti telah diuraikan di bagian depan bahwa seorang dalang harus menguasai isi lontar Dharma Pewayangan secara baik, terutama yang ada kaitannya langsung dengan "profesinya" sebagai pertunjukan wayang kulit. Di awal atau pendahuluan lontar Dharma Pewayangan secara implisitmenyebutkan bahwa apa sebenarnya fungsi lontar tersebut bagi para dalang. Membuat tirta panglukatan/panyudamalan, mengambil pasepan/ dupa, mantranya: "Ong Ang Astra - KalagniRudra ya namah". Coblong/Sangku berisi toya anyar (air bersih), mantranya: "Ong Ganggamrta ya namah swaha”, kemudian dipercikkan kepada semua wayang dan sesajennya sebanyak $3 x$.

Om, gangga muncar saking purwa, tininggalana telaga noja, jambangania selaka, tinanceban tunjung petak, padyusanira betara Iswara, matemahan tirta sanjiwani, pangilanganing papa petaka, moksah ilang Sang namah.

Om, gangga muncar saking daksina, tininggalana telaga noja, jambangania tembaga, tinanceban tunjung bang, padyusanira betara Bhrahma, matemahan tirta kamandalu, pangilanganing sarwa wigena, moksah ilang Bang namah.
Om, gangga muncar saking pascima, tininggalana telaga noja, jambangania emas, tinanceban tunjung jenar, padyusanira betara Mahadew, matemahan tirta Kundalini, pangilanganing lara roga, moksah ilang Tang namah.

Om, gangga muncar saking utara, tininggalana telaga noja, jambangania wesi, tinanceban tunjung ireng, padyusanira betara Wisnu, matemahan tirta mahamerta, pangilanganing sarwa satru, moksah ilang Ang namah.

Om, gangga muncar saking madya, tininggalana telaga noja, jambangania amancawarna/kawah, tinanceban tunjung manca warna, padyusanira betara Siwa, matemahan tirta pawitra, pangilanganing tri mala, panca mala, dasa mala, moksah ilang ing namah.

Ong serdah paduka betara Siwa Murti sakti, anibakaken tirta kamandalu, winadahan kundi manik, maka suklaning bhuana agung bhuana alit maka uriping bhuana kabeh, amuburana ujar ala, tuju, teluh, desti trangjana, kalukat denira tirtan betara Siwa Murti Sakti, siniratan muncrat mancur, angilangaken papa klesa, dasa mala manusa kabeh, Ong sidi rastu tatastu astu swaha.

Terjemahan:

Tuhan dalm wujud Siwa maha sakti, memercikkan air suci yang ada di dalam kendi mas manikam, sebagai penyucian makrokosmos dan mikrokosmos, yang menghidupkan dunia tersebut, dan membakar serta melebur segala nista, teluh, penyakit, segala ilmu gaib, dilebur oleh percikan air suci dewa Siwa yang maha sakti, percikan maha suci ini menghilangkan segala segala kesengsaraan semua mahluk (manusia), Tuhan semua kehendakmu pasti terwujud

\section{Kesimpulan}

Dari uraian di atas mengenai proses, 
fungsi dan makna mantra Dharma Pewayangan yang digunakan oleh Jro Mangku Dalang dalam pertunjukannya, merupakan keyakinan teologi dalam melaksanakan "swaginanya".

1. Proses penggunaan mantra ini dimulai sebelum brangkat "ngewayang", yaitu menghaturkan sesaji di "merajan" sebagai "nyasa upasaksi" kehadapan Tuhan baik dalm wujud "Taksu" maupun "leluhur". Setelah itu, Jro Mangku Dalang menggunakan mantra keluar dari pekarangan rumah, dilanjutkan dengan mantra saat berada di jalan. Mantra selanjutnya adalah pada saat tiba di rumah penanggap wayang, kemudian duduk, dan makan. Setelah makan dilanjutkan dengan mantra duduk dibawah lampu "blencong", terus mantra "nginang" mantra membuka tutup gedog, membuka kain "kasa" penutup wayang, dan dilanjutkan dengan mantra mengeluarkan wayang kayonan. Setelah pertunjukan selesai, Jro Mangku Dalang menggunakan mantra sesuai dengan sesaji yang tersedia, utamanya adalah mantra membuat "tirta". Jika diperlukan "nglukat" maka Jro Mangku Dalang memakai mantra "penglukatan" dan terakhir mantra menyimpan wayang.

2. Fungsi penggunaan mantra adalah sebagai permohonan anugrah sesuai dengan yang dikehendaki oleh Jro Mangku Dalang. Selain itu juga berfungsi untuk menjaga diri dari segala macam ancaman kususnya ancaman yang bersifat mistis. Fungsi yang lainnya adalah untuk membangkitkan karismatik atau "taksu", sehingga segala yang dilakukan lewat media wayangnya dapat menarik hati penonton. Yang paling nyata adalah digunakan untuk membuat air suci atau "tirta", kususnya tirta "sudamala dan ruwatan".

\section{DAFTAR PUSTAKA}

Bandem, 1994. Mengembangkan Lingkungan Sosial yang Mendukung Wayang, dalam Mudra Jurnal Seni Budaya No. 2 TH. 2
Februari 1994. Denpasar: STSI

Hooykaas, C, 1973. Kama and Kala Material for study of shadow theatre in Bali. NorthHolland Publishing Company-Amsterdam. London.

Mulyono, Sri, 1978. Wayang, Asal-usul, Filsafat dan Masa Depannya. Jakarta: PT. Gunung Agung

Mulyono, Sri,, 1979. Simbolisme dan Mistikisme dalam Wayang, Sebuah Tinjauan Filosofis. Jakarta: PT. Gunung Agung,

Rota, Ketut. 1988. Retorika dalam Pewayangan Bali. Denpasar: STSI

$\neg$ Rota, Ketut. 1994. Pertunjukan Wayang Kulit Bali Sebagai Sarana Pendidikan Budi Pekerti: Suatu Kajian Fenomenologis;( Pidato Pengukuhan Jabatan Guru Besar Tetap Dalam Ilmu Pedalangan Pada Sekolah Tinggi Seni Indonesia Denpasar).

Sudha, Ida Bagus Raka. 1980. Manusa Yadnya Dalam Hubungannya Dengan Wayang Sapuh Leger.Fakultas Agama dan Kebudayaan. Denpasar: Institut Hindu Dharma

Sugriwa, I Gusti Bagus. 1963. Ilmu Pedalangan/ Pewayangan, Konservatori Karawitan Indonesia, Jurusan Bali, Denpasar.

Tim Penyusun Kamus Pusat Pembinaan dan Pengembangan Bahasa, 1988. Kamus Besar Bahasa Indonesia, Departemen Pendidikan Dan Kebudayaan republik Indonesia Jakarta.

Titib, I Made. 2001. Teologi dan Simbol-Simbol Dalam Agama Hindu. Badan Litbang Parisada Hindu Dharma Indonesia Pusat Bekerjasama Dengan Surabaya: Paramita

Widnyana,I Kadek. 2004. Purwa-Wasana Metode Penuntun Belajar Mendalang. Dalam Mudra Jurnal Seni Budaya Volume 14 No. 1 Januari 2004. ISI Denpasar.

Widnyana,I Kadek 2013. Tradisi Nginang Dalang Bali Sebuah Kajian Sosial dan Teologi. Jurnal Ilmiah Seni Pewayangan. Volume 12 No. 1 September 2013. Jurusan Seni Pedalangan 
Fakultas Seni Pertunjukan Institut seni Indonesia Denpasar. 